\title{
Monitoring Passive Transfer of Immunity in Neonatal Calves by Measuring Levels of IgG in Blood Using Immunoassay Method and Refractometer Measures of Serum and Colostrum
}

\author{
Osman A. Hameed1*, Hussam Mustafa², Abdul Fatah M. Ahmed3', Mohamed Khidr Taha4 \\ ${ }^{1}$ Central Veterinary Laboratory, Khartoum, Sudan \\ ${ }^{2}$ Sharge Elnile Colleague of Laboratory Science, Khartoum, Sudan \\ ${ }^{3}$ Nyala University of Veterinary Science, Nyala, Sudan \\ ${ }^{4}$ Faculty of Veterinary Medicine, Khartoum University, Khartoum, Sudan \\ Email: ^osmanhs@yahoo.com
}

How to cite this paper: Hameed, O.A., Mustafa, H., Ahmed, A.F.M. and Taha, M.K. (2019) Monitoring Passive Transfer of Immunity in Neonatal Calves by Measuring Levels of IgG in Blood Using Immunoassay Method and Refractometer Measures of Serum and Colostrum. Open Journal of Veterinary Medicine, 9, 194-201.

https://doi.org/10.4236/ojvm.2019.912017

Received: September 25, 2019

Accepted: December 21, 2019

Published: December 24, 2019

Copyright $\odot 2019$ by author(s) and Scientific Research Publishing Inc. This work is licensed under the Creative Commons Attribution International License (CC BY 4.0).

http://creativecommons.org/licenses/by/4.0/

\begin{abstract}
IgG Check calf test has been used in this study to identify if a failure of passive transfer occurs in neonatal calves by measuring the level of IgG in blood. An adequate level of IgG measured in all calves at 48 hours, 7 days and 14 days after birth showed level of IgG $1000 \mathrm{mg} / \mathrm{dl}$. This level indicated that they have good passive transfer of immunity. Also, in this study colostrum quality fed to calves was detected using Brix Refractometer. The colostrum is of high quality as it contains $50 \mathrm{mg} / \mathrm{ml}$ of IgG. This Brix refractometer can be used on the farm level to estimate colostrum IgG content and monitoring colostrum feeding practices. Colostrum with high quality IgG could provide calves with enough IgG to attain successful passive transfer of immunity. Brix and Obione refractometers provide simple, rapid method for estimating IgG concentration on calf serum, thus considered to be the most common method for determining passive transfer failure.
\end{abstract}

\section{Keywords}

Colostrum, Passive Immunity, Immunoglobulin G (IgG), Failure of Transfer Immunity (FTPI), Radial Immunodiffusion (RID), Turbidimetric Immunoassay (TA), Refractometer (REF), Brix refractometer (Brix), Obione Refractometer (Obione), IgG Check Calf Immunoassay, High Quality Colostrum, Inadequate Transfer of Passive Immunity (ITPI) 


\section{Introduction}

The new-born calf is highly dependent on colostrum intake to acquire adequate passive immunity during the neonatal period. The quality of transfer of passive immunity is most often practically assessed using serum immunoglobulin $G$ (IgG) concentration 1 - 6 days after birth.

Inadequate absorption of colostral IgG is termed failure of transfer of passive immunity (FTPI). Dairy calves with FTPI have increased mortality and morbidity in their first 6 months of life.

Transfer of passive immunity in calves can be assessed by direct measurement of immunoglobulin $\mathrm{G}$ (IgG) by methods such as radial immunodiffusion (RID) or turbidimetric immunoassay (TIA). IgG can also be measured indirectly by methods such as serum refractometry (REF) or Brix refractometry (BRIX).

Measurement of serum IgG concentrations is considered to be the most common method for determining passive transfer failure in neonatal calves and a serum IgG concentration of $>10 \mathrm{~g} / \mathrm{L}$ is considered to be a criterion for providing sufficient passive immunity [1] [2] [3] [4].

IgG check for calf, which is a quantitative test of immunoglobulin $\mathrm{G}(\mathrm{IgG})$ in a drop of bovine whole blood was developed [5]. It will identify if a failure of passive transfer has occurred by measuring the level of IgG in the blood. An adequate level of $\operatorname{IgG}$ is $1000 \mathrm{mg} / \mathrm{dl}$ or greater. Levels less than $500 \mathrm{mg} / \mathrm{dl}$ indicate inadequate passive transfer. A rapid identification of low IgG level is very important for the early initiation of treatment of immunodeficient calves.

Other practical methods to estimate serum IgG concentration have been investigated [6]. Among these methods, optical or digital refractometry (REF) and Brix refractometry (BRIX) have been suggested as methods to assess serum IgG concentration. The cut off-point at which Brix values indicated successful passive transfer of immunity (IgG $\geq 10 \mathrm{~g} / \mathrm{L}$ ) has been determined by some authors [7] [8] [9]. Morrill et al., reported the regression equation for BRIX and serum IgG. That equation: $9.12846 \mathrm{x}-59.2122$, allows us to predict the serum IgG at any given BRIX value between 3.5 and $47 \mathrm{~g} / \mathrm{L}$.

The advantages of the BRIX refractometer are that it is equally accurate; it can predict serum IgG instead of total protein (which must then be used to estimate IgG); and the BRIX refractometer is usually much less expensive.

Colostrum containing $50 \mathrm{mg} / \mathrm{mL}$ or more of $\operatorname{IgG}$ is considered to be a high-quality feed for newborn calves. A Brix value of $22 \%$ corresponds to 50 $\mathrm{mg} / \mathrm{mL}$, meaning colostrum with a Brix value above this cut off point can be considered high quality colostrum.

\section{Materials \& Methods}

The study was performed using 5 Holstein calves, imported from the Netherlands. IgG serum concentration from each calf was measured using IgG check immunoassay kits manufactured by Portacheck, USA. The test was performed according to manufacture instruction (As per illustrated below diagram, Figure 
1). Blood was collected from each calf 48 hours, 7 days and 14 day after birth and tested using the kit. Results were recorded after 10 minutes. Very good transfer of immunity corresponds to $1000 \mathrm{mg} / \mathrm{dl}$ in blood (Test line is much darker than control line) while partial failure of immunity corresponds to 700 $\mathrm{mg} / \mathrm{dl}$ (Test line and control line are both faint). Total failure of passive immunity corresponds to $500 \mathrm{mg} / \mathrm{dl}$ (control line is darker than test line).

The BRIX refractometer is commonly used in the brewing industry to measure the sugar concentration of liquids. It had been learned that the BRIX refractometer estimates of BRIX \% are closely related to colostrum IgG concentration; consequently, it was recommend using the BRIX refractometer to estimate colostrum IgG concentration. Quality of colostrum fed for each calf was measured using Brix refractometry. Colostrum containing $50 \mathrm{mg} / \mathrm{ml}$ or greater of $\mathrm{IgG}$ is considered of high quality. A Brix value of $22 \%$ corresponds $50 \mathrm{mg} / \mathrm{ml}$ so a Brix value above this this cut off point is considered highly quality colostrum.

For the prediction of serum [9], IgG Morrill et al. (2013) reported the regression equation for BRIX and serum IgG. That equation: 9.12846x - 59.2122, allows us to predict the serum IgG at any given BRIX value between 3.5 and 47 g/L.

For example, if we measure the BRIX value of a sample of serum and it reads $7.5 \%$ BRIX, the estimated serum IgG concentration $=9.12846 \times 7.5-59.2122=$ $9.25 \mathrm{~g} / \mathrm{L}$. In this case, the estimated serum IgG concentration indicates the calf did NOT receive enough passive immunity and is more susceptible to disease. Serum protein IgG concentrations were measured using Brix and compared with that of Obione digital Refractometer. Serum from each 5 calf was harvested 7 days and 14 days after birth and IgG protein concertation is detected. A serum of digital Brix percentage $<7.8$ and a serum total IgG concentration $<10 \mathrm{~g} / 1$ were defined as failure of transfer of passive immunity (FTPI).

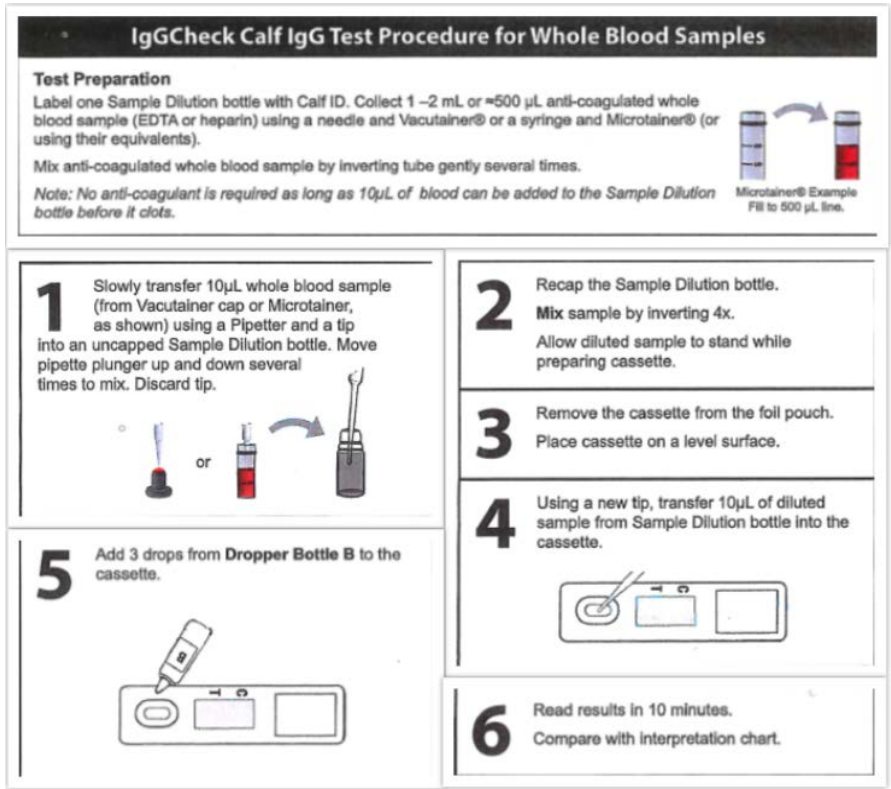

Figure 1. IgG check test Procedure diagram. 


\section{Result}

IgG levels of all calves 48 hours, 7 day and 14 days after birth measured by IgG Check calf test showed very good transfer corresponds to $\geq 1000 \mathrm{mg} / \mathrm{dl}$ in blood (Table 1, Figures 3-5).

Colostrum quality fed to all calves as per Brix reading was of high quality as their reading is above the cut-off point of $22 \%$ (Table 2). This value corresponds to $50 \mathrm{mg} / \mathrm{ml}$ which is considered a colostrum of high quality.

Serum IgG protein concentration reading of all calves at 7 days of birth were more than $10 \%$ according to Brix reading value and were more than $30 \mathrm{~g} / \mathrm{l}$ as per Morril equation (Table $3 \&$ Table 4, Figure 6).

Serum IgG protein concentration of two calves at 14 days of birth measured by Brix refractometer were $8 \%$ while they were $7.6 \%$ and $8 \%$ as per Obione refractometer. These values were more than $10 \mathrm{~g} / \mathrm{l}$ as per Morril equation (Table 3 \& Table 4)

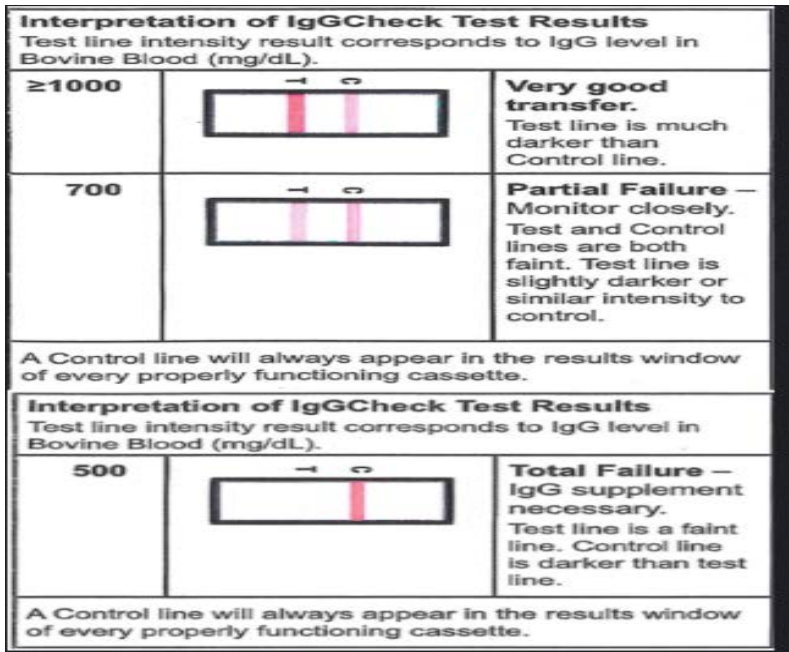

Figure 2. Interpretation results diagram of IgG check test.

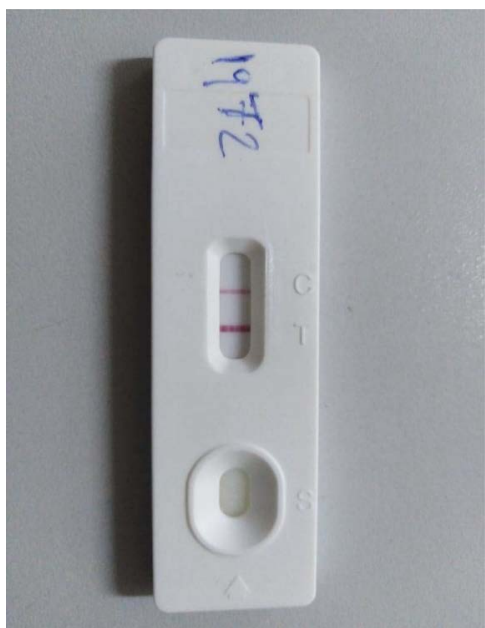

Figure 3. IgG concentrations at 48 hours after birth corresponds to $\geq 1000 \mathrm{mg} / \mathrm{dl}$. 


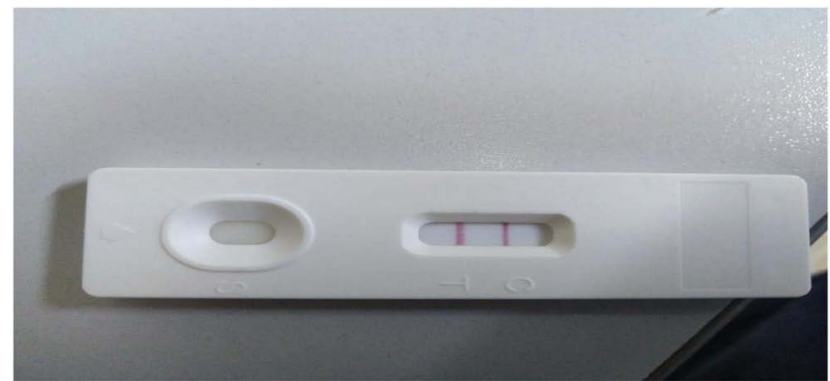

Figure 4. IgG concentration at 7 days after birth corresponds to $\geq 1000 \mathrm{mg} / \mathrm{dl}$.

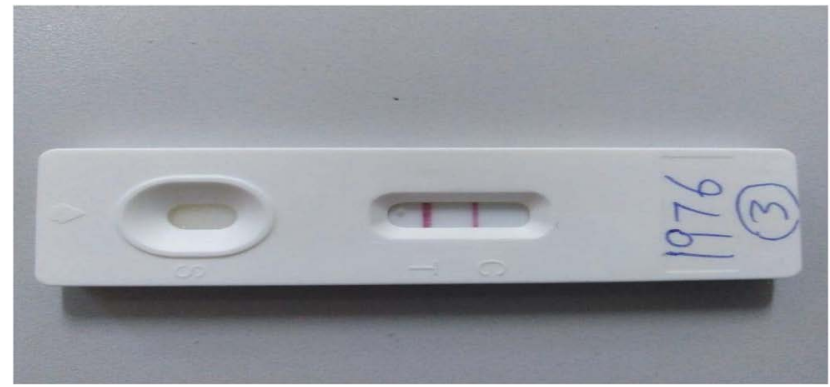

Figure 5. IgG concentration 14 days after birth corresponds to $\geq 1000 \mathrm{mg} / \mathrm{dl}$.

Table 1. Calves IgG check interpretation results as per illustrated manufactured diagram, Figure 2 .

\begin{tabular}{ccccc}
\hline $\begin{array}{c}\text { Calf } \\
\text { Number }\end{array}$ & $\begin{array}{c}\text { Date } \\
\text { of Birth }\end{array}$ & $\begin{array}{c}\text { IgG 48 Hour } \\
\text { after birth }\end{array}$ & $\begin{array}{c}\text { IgG 7 days } \\
\text { after birth }\end{array}$ & $\begin{array}{c}\text { IgG 14 days } \\
\text { after birth }\end{array}$ \\
\hline 4361 & $5 / 5 / 2019$ & *Very Good & *Very Good & *Very Good \\
1969 & $8 / 5 / 2019$ & Very Good & Very Good & Very Good \\
1970 & $10 / 5 / 2019$ & Very Good & Very Good & Very Good \\
1972 & $12 / 5 / 2019$ & Very Good & Very Good & Very Good \\
1976 & $15 / 5 / 2019$ & Very Good & Very Good & Very Good \\
\hline
\end{tabular}

*Very Good transfer corresponds to $\geq 1000 \mathrm{mg} / \mathrm{dl}$ in blood (Test line is much darker than control line Partial failure transfer corresponds to $700 \mathrm{mg} / \mathrm{dl}$ in blood (Test line and control line are both faint). Total transfer failure corresponds to $500 \mathrm{mg} / \mathrm{dl}$ in blood (Control line is darker than test line).

Table 2. Colostrum Quality: All Colostrum quality tested were of good quality.

\begin{tabular}{ccc}
\hline $\begin{array}{c}\text { Calf } \\
\text { Number }\end{array}$ & $\begin{array}{r}\text { *Brix Colostrum } \\
\text { reading }\end{array}$ & $\begin{array}{c}\text { Colostrum } \\
\text { quality } / \mathrm{mg} / \mathrm{ml}\end{array}$ \\
\hline 361 & $26 \%$ & Good $>50 \mathrm{mg} / \mathrm{ml}$ \\
1969 & $29 \%$ & Good $>50 \mathrm{mg} / \mathrm{ml}$ \\
1970 & $30 \%$ & Good $>50 \mathrm{mg} / \mathrm{ml}$ \\
1972 & $29 \%$ & Good $>50 \mathrm{mg} / \mathrm{ml}$ \\
1976 & $26 \%$ & Good $>50 \mathrm{mg} / \mathrm{ml}$
\end{tabular}


Table 3. Brix and Obione Calf Digital results.

\begin{tabular}{cccc}
\hline $\begin{array}{c}\text { Calf } \\
\text { Number }\end{array}$ & $\begin{array}{c}* * \text { Brix serum reading } \\
7 \text { days after birth }\end{array}$ & $\begin{array}{c}* * \text { Obione Serum reading } \\
14 \text { days after birth }\end{array}$ & $\begin{array}{c}* * * \text { Brix serum reading } \\
14 \text { days after birth }\end{array}$ \\
\hline 4361 & $10.2 \%$ & $5.7 \%$ & $5.8 \%$ \\
1969 & $10.2 \%$ & $8 \%$ & $8 \%$ \\
1970 & Not tested & $5.1 \%$ & $5 \%$ \\
1972 & $10.7 \%$ & $7.6 \%$ & $8 \%$ \\
1976 & $10 \%$ & $5 \%$ & $5.7 \%$ \\
\hline
\end{tabular}

Table 4. Prediction of Serum IgG Protein using Morril equation (9.12845x Brix value -59.2122).

\begin{tabular}{ccccccc}
\hline Calf No. & $\begin{array}{c}\text { Brix value } \\
\text { at 7 days }\end{array}$ & $\begin{array}{c}\text { Serum IgG, } \\
\mathrm{g} / \mathrm{l}\end{array}$ & $\begin{array}{c}\text { Obione value } \\
\text { at } 14 \text { days }\end{array}$ & $\begin{array}{c}\text { Serum IgG, } \\
\mathrm{g} / \mathrm{l}\end{array}$ & $\begin{array}{c}\text { Brix value at } \\
14 \text { days }\end{array}$ & $\begin{array}{c}\text { Serum IgG, } \\
\mathrm{g} / \mathrm{l}\end{array}$ \\
\hline 4361 & $10.2 \%$ & 33.89 & $5.7 \%$ & -7.718 & 5.8 & -6.2 .7 \\
1969 & $10.2 \%$ & 33.89 & $8 \%$ & 13.81 & 8 & 13.82 \\
1970 & - & - & $5.1 \%$ & -12.65 & 5 & -13.56 \\
1972 & $10.7 \%$ & 38.46 & $7.6 \%$ & 10.16 & 8 & 13.81 \\
1976 & $10 \%$ & 32.07 & $5 \%$ & -0.08 & 5.7 & -7.718 \\
\hline
\end{tabular}

Serum IgG protein concentration of the remaining 3 calves at 14 days of birth measured by Brix were less than $7.6 \%$ as per Obione refractometer (Figure 7) and were less than $8 \%$ as per Brix refractometer. Their reading value is less than $10 \mathrm{~g} / \mathrm{l}$ as per Morril equation (Table $3 \&$ Table 4 ).

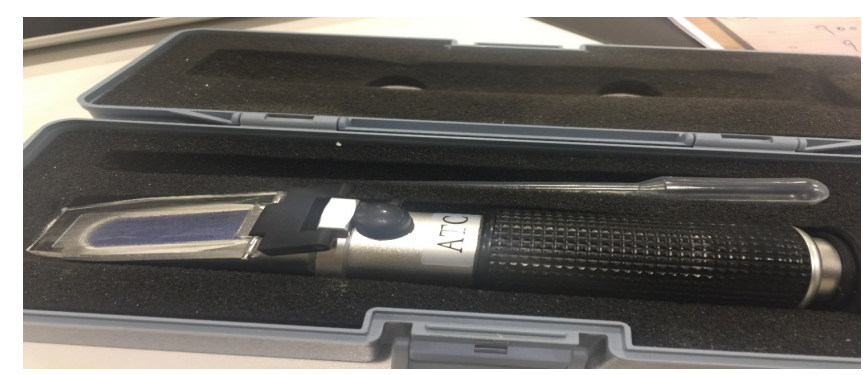

Figure 6. Brix refractometer.

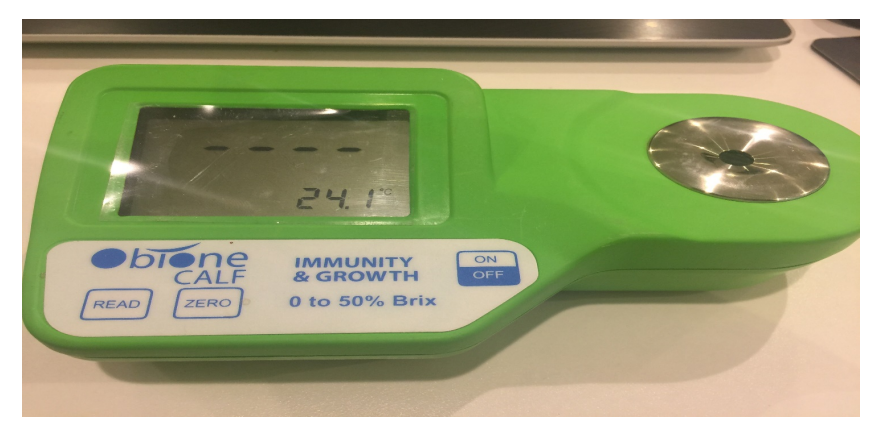

Figure 7. Obione refractometer. 


\section{Discussion}

Calves are born with no immunoglobulins (IgG) and must receive adequate antibodies from the cows colostrum (passive transfer or IgG). Failure of passive transfer can occur as a result of premature lactation, deficient suckling, malabsorption or low IgG levels in the cows colostrum.

IgG check test used in this study identified the passive or failure transfer by measuring the level of IgG in blood. IgG level measured for all calves 48 hours, 7 days and 14 days after birth measured IgG level of $\geq 1000 \mathrm{mg} / \mathrm{dl}$ which means that they have a very good passive transfer.

Concentration of IgG in colostrum varies according to many factors, including a cow's disease history, volume of colostrum produced, season of the year, and breed. Research has shown that IgG levels vary widely from one cow to the next and range from less than 20 to over $100 \mathrm{mg} / \mathrm{ml}$. The difference between 20 and $100 \mathrm{mg} / \mathrm{mL}$ of IgG in colostrum can mean the difference between failure and success in passive transfer of immunity. Colostrum containing $50 \mathrm{mg} / \mathrm{mL}$ or more of IgG is a high-quality feed for newborn calves. Measurement of IgG concentrations in colostrum can be very useful in managing colostrum quality and monitoring colostrum feeding practices.

Colostrum quality fed to all calves in this study as per Brix reading were above the cut off point $22 \%$. This value corresponds to $50 \mathrm{mg} / \mathrm{ml}$ which is considered a colostrum of high quality.

Measurement of serum IgG concentrations is the most common method for determining passive transfer failure in neonatal calves and a serum IgG concentration of $>10 \mathrm{~g} / \mathrm{L}$ is a criterion for providing sufficient passive immunity.

Serum IgG protein concentration at 7 days of birth were more than $10 \%$ (Brix value) which were more than $30 \mathrm{~g} / \mathrm{l}$. These results indicate that calves at 7 days of age have good passive transfer of immunity. However, calves at 14 days of birth only 2 calves have serum IgG protein concentration more than $30 \mathrm{~g} / \mathrm{l}$. The remaining 3 calves have IgG serum protein less than $10 \mathrm{~g} / \mathrm{l}$. Serum $\operatorname{IgG}<10 \mathrm{~g} / \mathrm{L}$ has been traditionally used as an acceptable threshold for defining inadequate transfer of passive immunity (ITPI).

\section{Conclusions}

IgG Check calf test is a rapid useful tool to identify IgG level of new-born calves. A rapid identification of low IgG level is very important for the early initiation of treatment of immunodeficient calves.

A BRIX refractometer is a simple tool measuring colostrum quality thus predicting the success of the colostrum feeding program.

The other advantage of the BRIX refractometer is that it can predict serum IgG concentration and is the common method for determining passive transfer failure in neonatal calves.

\section{Acknowledgements}

The authors thank Toni Hopkins, Rachel Jeronimus, Porta Check, USA for pro- 
viding IgG Check calf test used in this study and for their technical assistance. In addition, the authors thank Loay Abiad, dairy consultant at Artat Enterprise, KSA, for providing Obione Refractometer used in this study.

\section{Conflicts of Interest}

The authors declare no conflicts of interest regarding the publication of this paper.

\section{References}

[1] Quigley, J.D. (2004) The Role of Oral Immunoglobulins in Systemic and Intestinal Immunity of Neonatal Calves. Iowa State University, Ames, IA.

[2] Jaster, H.E. (2005) Evaluation of Quality, Quantity, and Timing of Colostrum Feeding on Immunoglobulin G1 Absorption in Jersey Calves. Journal of Dairy Science, 88, 296-302. https://doi.org/10.3168/jds.S0022-0302(05)72687-4

[3] Abel Francisco, S.F. and Quigley, J.D. (1993) Serum Immunoglobulin Concentrations after Feeding Maternal Colostrum or Maternal Colostrum plus Colostral Supplement to Dairy Calves. American Journal of Veterinary Research, 54, 1051-1054.

[4] Fecteau, G.G., Arsenault, J., Pare, J., Van Metre, D.C., Holmberg, C.A., et al. (2013) Prediction of Serum Igg Concentration by Indirect Techniques with Adjustment for Age and Clinical and Laboratory Covariates in Critically Ill Newborn Calves. Canadian Journal of Veterinary Research, 77, 89-94.

[5] Dawes, M.E., Tyles, J.W., Hostetler, D., Lakritz, J. and Tessman, R. (2002) Evaluation of Immunoassay for Assessing Passive Transfer in Claves. JAVMA, 220, 791-793. https://doi.org/10.2460/javma.2002.220.791

[6] Lombardi, P., Avallone, L., Pagnini, U., D’angelo, D. and Bogin, E. (2001) Evaluation of Buffalo Colostrum Quality by Estimation of Enzyme Activity Levels. Journal of Food Protection, 64, 1265-1267.

https://doi.org/10.4315/0362-028X-64.8.1265

[7] Deelen, S., Ollivett, T., Haines, D. and Leslie, K. (2014) Evaluation of a Brix Refractometer to Estimate Serum Immunoglobulin G Concentration in Neonatal Dairy Calves. Journal of Dairy Science, 97, 3838-3844.

https://doi.org/10.3168/jds.2014-7939

[8] Elsohaby, I., McClure, J.T. and Keefe, G.P. (2015) Evaluation of Digital and Optical Refractometers for Assessing Failure of Transfer of Passive Immunity in Dairy Calves. Journal of Veterinary Internal Medicine, 29, 721-726. https://doi.org/10.1111/jvim.12560

[9] Morrill, K.M., Polo, J., Lago, A., Campbell, J., Quigley, J. and Tyler, H. (2013) Estimate of Serum Immunoglobulin G Concentration Using Refractometry with or without Caprylic Acid Fractionation. Journal of Dairy Science, 97, 4535-4541. https://doi.org/10.3168/jds.2012-5843 